\title{
VERBOND OF KONINKRYK ?
}

NAAS die teoloë wat geen integrerende eenheidslyn in die $\mathrm{Ou}$ Testament sien nie, omdat God se openbaring te ryk is om onder een tema saam te vat, of uit ander oorwegings wat nie nou hier ter sake is nie, is daar ook diegene wat wel meen dat hulle so 'n integrerende eenheidslyn daarin bespeur. Vir 'n breedvoerige bespreking hiervan kan ek verwys na dr. H. Denkema se artikel in hierdie blad, Jaargang 9, Nr. 33. Uit daardie artikel blyk tewens dat daar diegene is wat sê dat die verbondsgedagte die integrerende eenheidslyn vorm, terwyl daar andere is wat weer die koninkryksgedagte as die sentrale tema van die O.T. sien. Onder eersgenoemdes is die mees bekende seker Walter Eichrodt. ${ }^{2}$ Onder laasgenoemdes is die mees bekendes vir ons John Bright, ${ }^{2} \mathrm{~S}$. du Toit $^{3}$ en J. L. Helberg. ${ }^{4}$

By die eerste van hierdie drie kom die verbondsgedagte maar baie sydelings ter sprake, miskien veral omdat hy in die benadering van die koninkryksgedagte so sterk by die Dawidiese koningskap aansluit en nie by die skepping of die Sinaitiese Verbond nie. By $\mathrm{Du}$ Toit kom die verbond nouliks ter sprake, selfs in die bespreking van die Sinaitiese Wetgewing. Die verhouding Koninkryk-Verbond kom eintlik nie ter sprake nie.

Nou wil ondergetekende nie daarop aanspraak maak om iets nuuts oor die saak te sê nie, maar net om aan te toon dat Verbond en Koninkryk eintlik maar twee aspekte van een saak is, en dat die integrerende eenheidslyn in die O.T. nie of die Verbond of die Koninkryk hoef te wees nie, maar beide, as twee aspekte van een saak.

Dit beteken eintlik maar net dat die lyne wat Helberg reeds aangedui het, verder in hulle konsekwensies deurgetrek word. Ek verwys veral na sy definisie van die Koninkryk in genoemde artikel. ${ }^{\circ}$ Dit lui: „Die soewereine, lewende God voer sy absolute heerskappy in en deur die geskiedenis deur, deur sy Woord, in persoonlike verbondsgemeenskap met die mensdom (kursivering van my), nieteenstaande hulle ten dode gevalle is".

Vir 'n verdere beredenering en uitbouing van hierdie standpunt wil ek verwys na die nou reeds bekend geworde studie van prof. George E. Mendelhall, ${ }^{\beta}$ omdat dit ons seker sal help om die verband tussen Verbond en Koninkryk beter te begryp.

Mendelhall het treffende en onthullende parallelle gevind in internasionale verdrae soos dit gedurende die tweede millennium voor Christus in westelike Asië gesluit is tussen die Hetitiese vorste en hulle bondgenote en vasalle. Veral die vorm van die soesereiniteitsverdrag tussen 'n groot koning en 'n vasalvors is hier van belang. Die soeserein word daarin genoem „die groot koning” en „die heer van die here". Die analogie tussen die posisie wat God teenoor sy onderdane beklee, is hier opvallend: $\mathrm{Hy}$ is immers die "Soeserein" wat oor alle magte heers, die Groot Koning (Ps. $95: 3$ ens.), DIE HERE van die leërskare.

Dit lyk of God die Verbond meermale gegiet het in die vorme 
wat vir die Hebreërs bekend was. So is die verbond met Abraham gegiet in ' $n$ vorm wat hy dadelik as verbond kon herken, sonder dat eers oor 'n verbond gepraat is. So was dit ook met die verbond wat by Sinai gesluit is.

In genoemde soesereiniteitsverdrae kom verskillende elemente voor wat ook op die verbond tussen God en Israel van toepassing is en wat heelwaarskynlik as model gedien het vir die Sinaïtiese Verbond:

1. In die aanhef van so ' $n$ verdrag stel die groot koning homself voor. Let op dat DIE HERE dit ook doen wanneer Hy die Verbond sluit, in die aanhef van die Dekaloog in Ex. $20: 2$ : „Ek is DIE HERE jou God ..."

2. Tweedens volg daar in genoemde soesereiniteitsverdrae 'n oorsig van die weldade van die groot koning en van sy grootmoedigheid wat aan die verbondssluiting ten grondslag lê. Let op die ooreenkoms hiervan met die woorde van Ex. $20: 2$; ,... wat jou uit Egipteland, uit die slawehuis, uitgelei het".

3. Daarna volg daar gewoonlik ' $n$ aantal bepalings. Daar is altyd 'n klousule in die verdrag wat die vasalvors belet om enige betrekkinge met ander konings aan te knoop. Let hier op die ooreenkoms met die eerste gebod van die Dekaloog: „Jy mag geen ander gode voor my aangesig hê nie" (Ex. 20:3).

4. Benewens verskeie ander trekke van ooreenkoms, kan ons nog net noem dat die verdrag gewoonlik afgesluit is met 'n lys van vervloekinge indien die vasal die verdrag sou verbreek wat ' $n$ mens dadelik herinner aan die lys van seëning en vervloekinge van Deut. 28. So opvallend is hierdie analogieë dat Meredith G. Kline van die Westminster Theological Seminary sy kommentaar oor Deuteronomium die titel gegee het van „The Treaty of the Great King".' Hy behandel die struktuur van die hele boek Deuteronomium op oortuigende wyse vanuit hierdie gesigspunt. Dit is terloops 'n baie sterk aanduiding dat die boek nie in die tyd van Josia eers ontstaan het nie, maar juis ten tyde van Moses, anders is dit moeilik om die spesifieke struktuur van die boek te verklaar.

Die belangrikste punt wat hom i.v.m. ons onderwerp aan ons opdring, is dit: die Verbondsluiter is die Groot Koning, die Koning van die konings en die Here van die here. Dit beteken dat by die verbondsluiting die koninkrykgedagte voorop moet staan en dat die verbondsgedagte nooit die koninkryksgedagte mag verdring of vervang nie. Wie hom hieraan sou skuldig maak, sou toon dat hy ook die verbondsgedagte nie verstaan nie.

Daar kan dus nie sprake wees van „Verbond of Koninkryk” nie. Dit is 'n onbybelse teëstelling. Die Verbond is die wyse waarop, of die weg waarlangs God sy Koninkryk op aarde vestig. Die Verbond is nodig omdat die mens nie vanself God se onderdaan wil wees nie. Hy moet eers langs die weg van Uitverkiesing en Verbond en Geloof in God se Koninkryk ingelyf word en sy onderdaan gemaak word.

Die Verbond is ' $n$ Koninkryksverbond en die Koninkryk is 'n Verbondskoninkryk.

Koos van Rooy (Hammanskraal). 


\section{In die Skriflig}

1 Sien bv. sy Theology of the Old Testament. London, SCM Press, 4th imp. 1975.

2 In: The Kingdom of God. New York, Abingdon Press, 1953.

3 In: Openbaringsgeskiedenis van die Ou Testament. Potchefstroom, 1962.

4 O.a. in: 'n Uitgangspunt en metode vir die studie van die Ou Testament. Ongepubliseerde lesing gehou tydens die aktualiteitskursus van die Teologiese Skool van die Gereformeerde Kerk, Potchefstroom, 1975.

5 Idem.

6 Onder die titel: Law and Covenant in Israel and the Ancient Near East. Pittsburgh, 1955. 